\title{
Defined Procedure Method Code
}

National Cancer Institute

\section{Source}

National Cancer Institute. Defined Procedure Method Code. NCI Thesaurus. Code C93792.

A coded value specifying the technique that is used for the procedure. 